\title{
Posmononocoor
}

2018, vol. 79, 97-110

http://dx.doi.org/10.12657/denbio.079.009

\author{
Dejan B. Stojanović, Tom Levanič, Bratislav Matović, \\ Stefan Stjepanović, Saša Orlović
}

\section{Growth response of different tree species (oaks, beech and pine) from SE Europe to precipitation over time}

Received: 5 September 2017; Accepted: 2 January 2018

\begin{abstract}
Changing climatic conditions can have various consequences for forest ecosystems, from increasing frequencies of forest fires, ice and windstorm events to pathogen outbreaks and mass mortalities. The Standardized Precipitation Index (SPI) was chosen for the evaluation of drought impact on the radial growth of trees after extensive preliminary testing of various calculated monthly climate parameters from the CARPATCLIM database.

SPI was calculated for periods between 3 and 36 months for different sites (lowland and mountainous parts of Serbia, Southeast Europe), from which Quercus robur, Q. cerris, Fagus sylvatica and Pinus sylvestris samples were acquired. Bootstrapped Pearson's correlations between SPI monthly indices and radial growth of tree species were calculated.

We found that 12-month SPI for summer months may be a good predictor of positive and negative growth of different species at different sites. The strongest positive correlations for five of six tree-ring width chronologies were between 12-month June and 14-month September SPI, which implies that high growth rates can be expected when the autumn of the previous year, and winter, spring and summer of the current year, are well supplied with precipitation, and vice versa (low precipitation in given period/low growth rates).
\end{abstract}

Keywords: Standardized Precipitation Index (SPI), climate change, tree mortality, Quercus sp., Fagus sylvatica, Pinus sylvestris

Addresses: D. B. Stojanović, B. Matović, S. Orlović, Institute of Lowland Forestry and Environment, University of Novi Sad, Antona Čehova 13d, 21000 Novi Sad, Serbia

T. Levanič, Slovenian Forestry Institute, Večna pot 2, 1000 Ljubljana, Slovenia, e-mail: tom.levanic@ gozdis.si

B. Matović, S. Orlović, Faculty of Agriculture, University of Novi Sad, Trg Dositeja Obradovića 8, 21000

Novi Sad, Serbia

S. Stjepanović, B. Matović, S. Orlović, Faculty of Agriculture, University of East Sarajevo, Vlasenica, Bosnia \& Herzegovina 


\section{Introduction}

Changing climatic conditions may have various consequences for forest ecosystems in the future, through altering the occurrence and character of drought, fires, ice and windstorm events, affecting also insect and pathogen outbreaks (Anderegg et al., 2015; Dale et al., 2001; Littell et al., 2016; Trumbore et al., 2015). Consequences may range from reduced growth of some regionally important species, such as European beech (Jump et al., 2006; Zimmermann et al., 2015) and pedunculate oak (Stojanović et al., 2015c), crown condition decline recorded for multiple species in Southern Europe (Carnicer et al., 2011), to increased mortality of temperate forests in California (van Mantgem \& Stephenson, 2007), tree mortality in Arizona (Mueller et al., 2005), decrease of productivity in Amazonia (Feldpausch et al., 2016), or mortality of forests on a wider scale (Allen et al., 2015; Allen et al., 2010).

Observed in terms of bioclimatic zones, projections of future climate predict that changing climate may have opposite effects, e.g., for continental Europe; from the expected predominantly adverse effects on forestry in the Mediterranean, to the potentially more positive effects in northern boreal regions, driven by significant increases in yearly precipitation by up to $40 \%$ and temperature increases by 3.5 to 5.8 ${ }^{\circ} \mathrm{C}$ by the end of the century (Lindner et al., 2010; Maracchi et al., 2005). In North America, where some recent projections have stated that a negative impact on forest growth is expected in the interior west and positive along the western, south-eastern and north-eastern coasts (Charney et al., 2016). A recent study by Bhuyan et al. (2017) showed that trees in the Mediterranean and temperate regions are more drought sensitive to short and intermediate-term drought, while trees in a continental climate are more drought resistant and respond to long-term drought. This is particularly true in lowlands with a continental climate, where an observed long-term drought was followed by an oak growth decrease and even stand-level mortality (Levanič et al., 2011; Stojanović et al., 2015b; Stojanović et al., 2015c).

This was not the case in the mountainous part within the studied region in Serbia. Climate and the response of European beech, which can be seen in the tree-ring width chronology (stand evaluated in Pretzsch et al. (2015), presented later in this study) had different patterns (general growth increase). Since climatic conditions, global temperature, precipitation amount, as well as drought event intensity, frequency and duration is changing and intensifying across the world, our intention was to analyse this phenomenon from the point of view of its impact on forest growth in a specific region, SE Europe.
Annual radial increment data from the region of Southeast Europe were used in this study. The radial growth of species from high importance genera on an international level - oaks (Quercus robur L. and Quercus cerris L.), beech (Fagus sylvatica L.) and pine (Pinus sylvestris L.), from different sites were evaluated. The advantage of this study is the detailed consideration of the SPI index of various lengths (3 to 36 months) and its relation to the growth response of different genera in a 50-year period along site and climatic gradients in a region of the central Balkan Peninsula. To understand how an abundance or lack of precipitation impacts on tree growth across time and space, we defined two main questions that will be tackled through the evaluation of relations among temperature, precipitation, SPI indices (3 to 36 months) and growth of different tree species:

1. Can the long-term impact of precipitation change be observed in the tree growth of different species in SE Europe?

2. Do past weather events reflect a memory effect on growth?

\section{Material and Methods}

\subsection{Stand, site, climate data and dendrochronological sampling}

Six TRW chronologies were evaluated within three genera at different sites characterised by low and high elevations, the occurrence of drought, and different climate patterns (Table 1, Fig. 1) - three pedunculate oak (Quercus robur $\mathrm{L}$ ) chronologies from managed and virgin stands from two sites in Srem (C1, C2) (Stojanović et al., 2015c) and Bačka (C3 and C4) regions, which experienced vitality decline in 2013 after long periods of drought in 2011 and 2012, a chronology of Turkey oak (Quercus cerris L.) from the Bačka region, from a stand that experienced mortality in 2013 due to prolonged drought (Stojanović et al., 2015b) and chronologies of European beech (Fagus sylvatica L.) and Scots pine (Pinus sylvestris L.), both from high elevation sites on Zlatibor mountain (C5 and C6) (Pretzsch et al., 2015).

We observed increased precipitation at all sites in the period 1991-2010 in comparison to the period $1961-1990$. Temperature also increased by $0.8-0.9^{\circ} \mathrm{C}$ at all sites for the same periods. The amplitude between environmental factors among sites, from lowlands towards mountainous sites, was $400 \mathrm{~mm}$ of rain, $4^{\circ} \mathrm{C}$ in temperature and $1000 \mathrm{~m}$ in elevation. While the oaks were growing in lowlands, in the basins of two large rivers (Sava and Danube) under continental climatic conditions, the beech and pine were growing on slopes at higher altitudes, in mountainous climatic conditions. 
Table 1. Description of sites and climate

\begin{tabular}{|c|c|c|c|c|c|c|c|c|c|}
\hline & Forest type & Mixing & Age & $\begin{array}{c}\text { Coordi- } \\
\text { nates }\end{array}$ & $\begin{array}{l}\text { Eleva- } \\
\text { tion } \\
(\mathrm{m})\end{array}$ & $\begin{array}{c}\text { Average an- } \\
\text { nual tempera- } \\
\text { ture } \\
1961-1990 \\
\left({ }^{\circ} \mathrm{C}\right)\end{array}$ & $\begin{array}{c}\text { Average } \\
\text { annual } \\
\text { temperature } \\
\text { 1991-2010 } \\
\left({ }^{\circ} \mathrm{C}\right)\end{array}$ & $\begin{array}{c}\text { Average } \\
\text { annual sum of } \\
\text { precipitation } \\
\text { 1961-1990 } \\
(\mathrm{mm})\end{array}$ & $\begin{array}{c}\text { Average an- } \\
\text { nual sum of } \\
\text { precipitation } \\
\text { 1991-2010 } \\
\text { (mm) }\end{array}$ \\
\hline Chron. 1 & $\begin{array}{l}\text { Quercus robur } \\
\text { (old-growth) }\end{array}$ & $\begin{array}{l}\text { mixed with } \\
\text { Carpinus betulus } \\
\text { and Fraxinus } \\
\text { angustifolia }\end{array}$ & $\sim 300$ & $\begin{array}{l}44.91^{\circ} \mathrm{N} \\
19.21^{\circ} \mathrm{E}\end{array}$ & $\sim 80$ & 11 & 11.8 & 695 & 755 \\
\hline Chron. 2 & $\begin{array}{l}\text { Quercus robur } \\
\text { (managed) }\end{array}$ & $\begin{array}{l}\text { mixed with } \\
\text { Carpinus betulus } \\
\text { and Fraxinus } \\
\text { angustifolia }\end{array}$ & $\sim 140$ & $\begin{array}{l}44.98^{\circ} \mathrm{N} \\
19.08^{\circ} \mathrm{E}\end{array}$ & $\sim 80$ & 11 & 11.8 & 695 & 755 \\
\hline Chron. 3 & $\begin{array}{l}\text { Quercus robur } \\
\text { (managed) }\end{array}$ & $\begin{array}{c}\text { mixed with } \\
\text { Quercus cerris L. }\end{array}$ & $\sim 120$ & $\begin{array}{l}45.47^{\circ} \mathrm{N} \\
19.17^{\circ} \mathrm{E}\end{array}$ & $\sim 85$ & 11.1 & 11.9 & 596 & 672 \\
\hline Chron. 4 & $\begin{array}{l}\text { Quercus cerris } \\
\text { (managed) }\end{array}$ & $\begin{array}{l}\text { mixed with } \\
\text { Quercus robur } \mathrm{L} \text {. }\end{array}$ & $\sim 120$ & $\begin{array}{l}45.47^{\circ} \mathrm{N} \\
19.17^{\circ} \mathrm{E}\end{array}$ & $\sim 85$ & 11.1 & 11.9 & 596 & 672 \\
\hline Chron. 5 & $\begin{array}{l}\text { Fagus sylvatica } \\
\text { (managed) }\end{array}$ & $\begin{array}{l}\text { mixed with } \\
\text { Pinus sylvestris } \\
\text { L., even-aged }\end{array}$ & $\sim 90$ & $\begin{array}{l}43.70^{\circ} \mathrm{N} \\
19.62^{\circ} \mathrm{E}\end{array}$ & $\sim 1100$ & 7.1 & 8.0 & 965 & 1040 \\
\hline Chron.6 & $\begin{array}{l}\text { Pinus sylvestris } \\
\text { (managed) }\end{array}$ & $\begin{array}{l}\text { mixed with } \mathrm{Fa}- \\
\text { gus sylvatica } \mathrm{L} \text {. }\end{array}$ & $\sim 120$ & $\begin{array}{l}43.70^{\circ} \mathrm{N} \\
19.62^{\circ} \mathrm{E} \\
\end{array}$ & $\sim 1100$ & 7.1 & 8.0 & 965 & 1040 \\
\hline
\end{tabular}

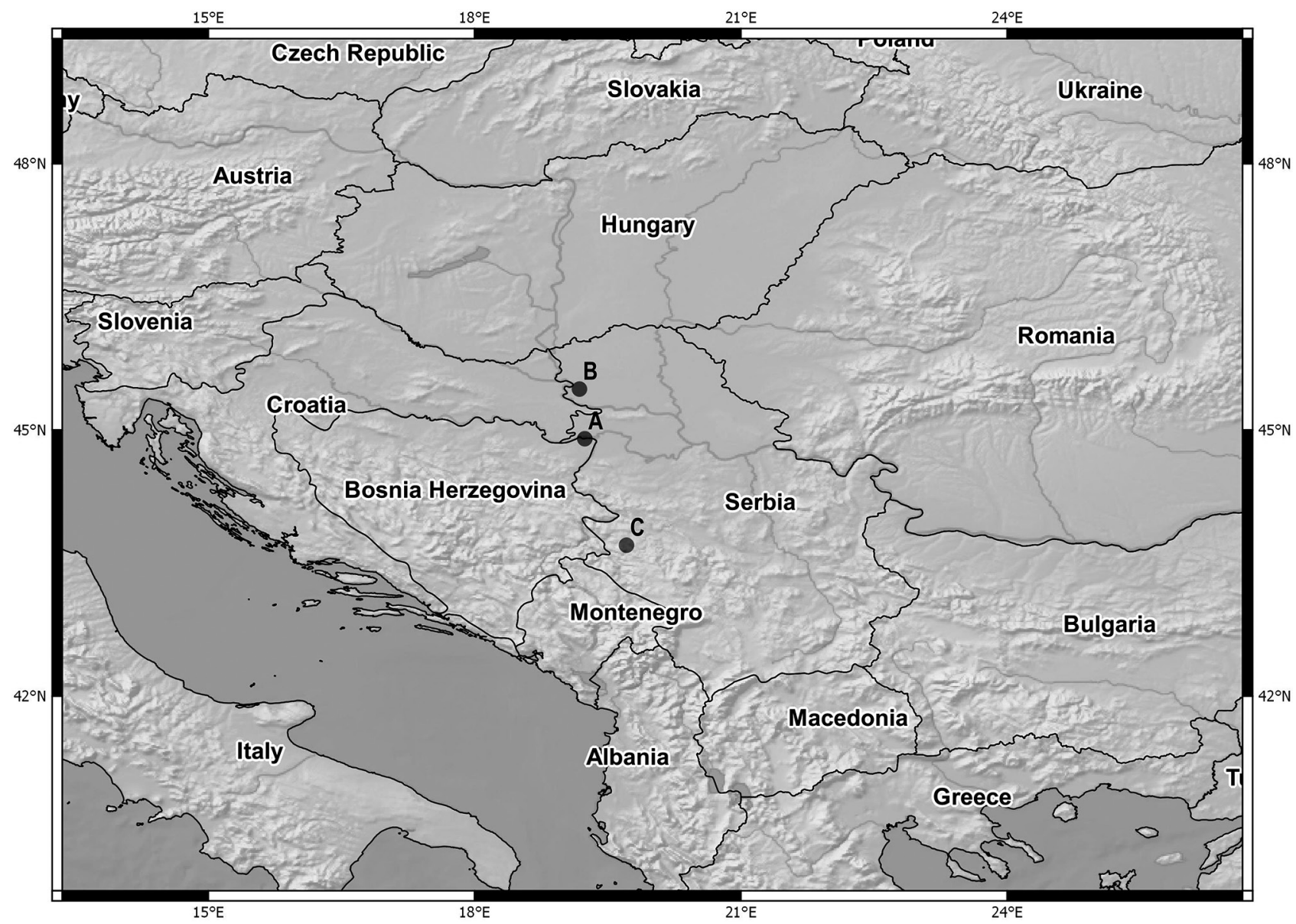

Fig. 1. Locations of the studied forest sites. Location A is Srem, a low-elevation site with managed and old-growth pedunculate oak (Quercus robur) stands, site B is Bačka, a low-elevation site with managed pedunculate oak and Turkey oak (Quercus cerris) stands and site $\mathrm{C}$ is the high-elevation site Zlatibor, with managed European beech (Fagus sylvatica) and Scots pine (Pinus sylvestris) stands 
Climate data for this study was acquired from two sources - from the CARPATCLIM database (Szalai et al., 2013) for all low elevation sites (Bačka and Srem) and from Zlatibor meteorological station for high elevation sites. The range of available meteorological data from both databases is from 1961 to 2010 .

Tree sampling and the applied dendrochronological sample preparation and measurements have been described in detail for pedunculate oak from the Srem region (two TRW chronologies; Stojanović et al., 2015c) for Turkey and pedunculate oak in the Bačka region (Stojanović et al., 2015b) and European beech and Scots pine from Zlatibor mountain region (Pretzsch et al., 2015).

Briefly, each species was represented by 10 to 20 trees. From dominant trees, two cores from the opposite sides were taken at breast height $(1.3 \mathrm{~m})$ or sections from stem discs at $1 / 5$ th of the height. Samples were dried and sanded with progressively finer sandpaper (Stokes \& Smiley, 1968). Samples were then scanned using the high resolution ATRICS system (Levanič, 2007), tree-ring widths were measured using WinDENDRO (www.regentinstruments.com) and chronologies were cross dated and synchronized in PAST- $5^{\mathrm{TM}}$ software (Www.sciem.com) using visual on-screen comparisons, as well as established statistical parameters - $\mathrm{t}$-value after Baillie and Pilcher $-t_{B P}$ (Baillie \& Pilcher, 1973) and Gleichläufigkeit coefficient - GLK\% (Eckstein \& Bauch, 1969). Individual tree-ring width (TRW) series were standardized using ARSTAN for Windows to remove longterm trends (Cook, 1985; Cook \& Holmes, 1999). Each series of tree-ring widths was fitted with a cubic smoothing spline with a $50 \%$ frequency response at $67 \%$ of the series length to remove non-climatic trends due to age, size and the effects of stand dynamics, to get a dimensionless index with a mean of one. Index values were then pre-whitened using an autoregressive model to remove autocorrelation. We thus produced a residual chronology for each studied tree species, containing only high-frequency variations with statistically removed autocorrelation (abbreviated as TRWi in the text).

\section{Study preparation and calculations}

The Standardized Precipitation Index (SPI) was chosen after extensive preliminary testing of various calculated monthly climate parameters from the CARPATCLIM project database - CARPATCLIM Database (C) European Commission - JRC, 2013 www. carpatclim-eu.org, (Szalai et al., 2013). The bootstrapped Pearson's correlation between oak tree-ring width (TRW) chronologies and temperature, precipitation and different drought indices (Palmer Drought Severity Index - PDSI, Standardized Precipitation Index - SPI 3, 6 and 12, Standardized Precipitation
Evapotranspiration Index - SPEI 3, 6 and 12 and Reconnaissance Drought Index - RDI 3, 6 and 12) for the period 1961-2010 (full period available from the database) were chosen or calculated from a database that has more than 50 daily, monthly and annual variables. Part of the analysis was presented in Stojanović et al. (2015a). Higher response coefficients between TRW chronologies and climate variables were observed for PDSI (Alley, 1984), SPI 12 (Guttman, 1999; McKee et al., 1993), SPEI 12 (Beguería et al., 2013; Vicente-Serrano et al., 2010), and RDI 12 (Asadi Zarch et al., 2011; Tsakiris et al., 2007).

Of these four drought indices, which provided comparably high correlations with TRW (Stojanović et al., 2015a), SPI was the simplest and the only one that does not include calculation of potential evapotranspiration. Earlier research emphasized SPI advantages over the Palmer Drought Severity Index in terms of spatial consistency and easier interpretation (Guttman, 1998). Since the inclusion of potential evapotranspiration in the calculation means the introduction of an additional variable, uncertainty and inhomogeneity on a larger scale, SPI has an advantage over PDSI, SPEI and RDI based on the criteria of uniformity and simplicity in application and understanding.

SPI was calculated using the SPEI package in the $\mathrm{R}$ programme (Beguería et al., 2013) for periods between 3 and 36 months. Since SPI takes into calculation the previous year's conditions, we limited correlation calculations to the year of ring formation (February to September). Correlations between SPI and six TRW chronologies of four tree species from two low and one high elevation sites were calculated using the bootRes R package (Zang \& Biondi, 2013).

\section{Results}

\section{Correlation between growth and SPI}

The radial increment at the six sites showed different temporal dynamics. Analysis of non-standardised tree-ring widths (raw measurements) showed that pedunculate oak stands have shown a general decline of growth in the last 30-40 years at both low elevation sites, as have Turkey oak at low elevation and Scots pine at the high elevation site, while European beech at the high elevation site has in general had an increasing growth trend, apart from growth in the extremely dry period between 2010 and 2013 (Fig. 2).

To analyse climate growth relationship, we calculated bootstrapped correlations among mean monthly temperature, monthly sum of precipitation, drought indices including SPI from CARPATCLIM database and local meteorological stations and tree-ring width 


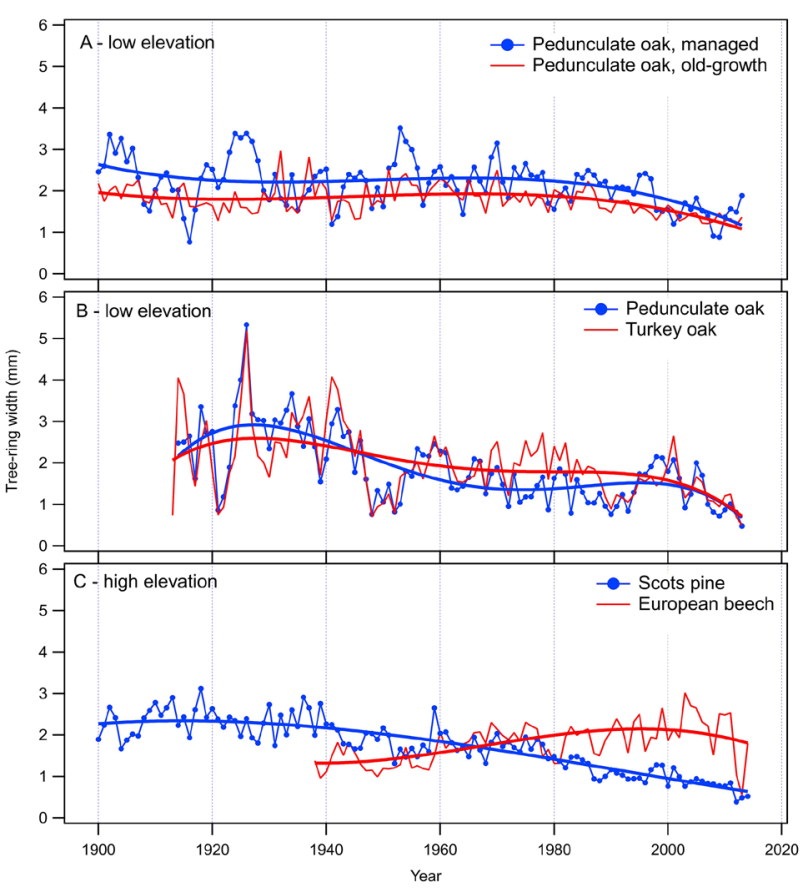

Fig. 2. Smoothed raw tree-ring width chronologies of European beech, Turkey oak, pedunculate oak and Scots pine from two low elevation (A and B) and one high elevation site $(\mathrm{C})$ showing different growth patterns

indices (TRWi). Both temperature and precipitation (Fig. 3) showed a correlation between TRWi and climate, although the results were not consistent and dependencies were fairly low. Trees from low elevation site B (Chron. $3 \& 4$ ) showed relatively high correlations with the monthly sum of precipitation in June and an inconsistent correlation with temperature. The comparable low elevation site $\mathrm{A}$, on the other hand, showed weak correlation between TRWi and precipitation and temperature (Chron. $1 \& 2$ ).

Beech and Scots pine at high elevation site $\mathrm{C}$ (Chron. 5 \& 6) also showed only weak to non-existent correlations between TRWi and climate. Beech

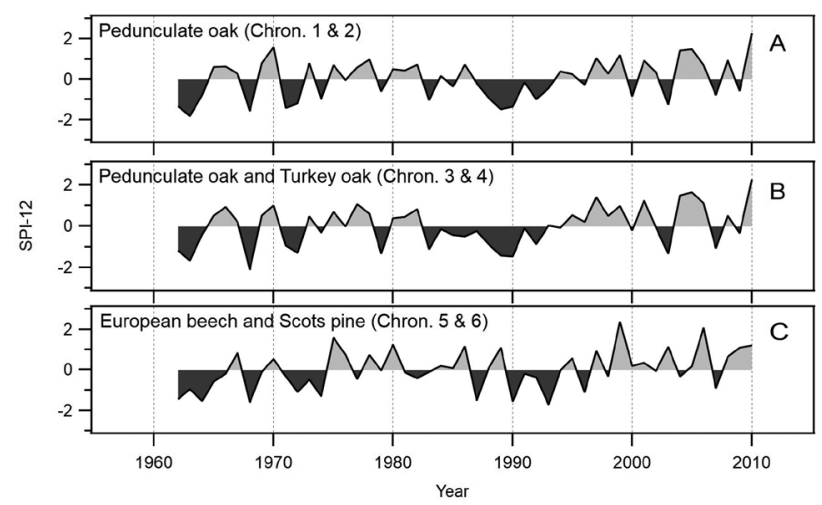

Fig. 4. Value of the July 12-month SPI coefficient for all three study sites - Srem (A), Bačka (B) and Zlatibor (C) with dominant tree species on site - Quercus robur (Srem and Bačka region), Quercus cerris (Bačka region) and Fagus sylvatica and Pinus sylvestris (Zlatibor region) had no response to temperature at all and a significant, positive correlation between June, July precipitation and TRWi. The response of Scots pine to climate at the high elevation site was non-conclusive. We only found three significant correlations, all of
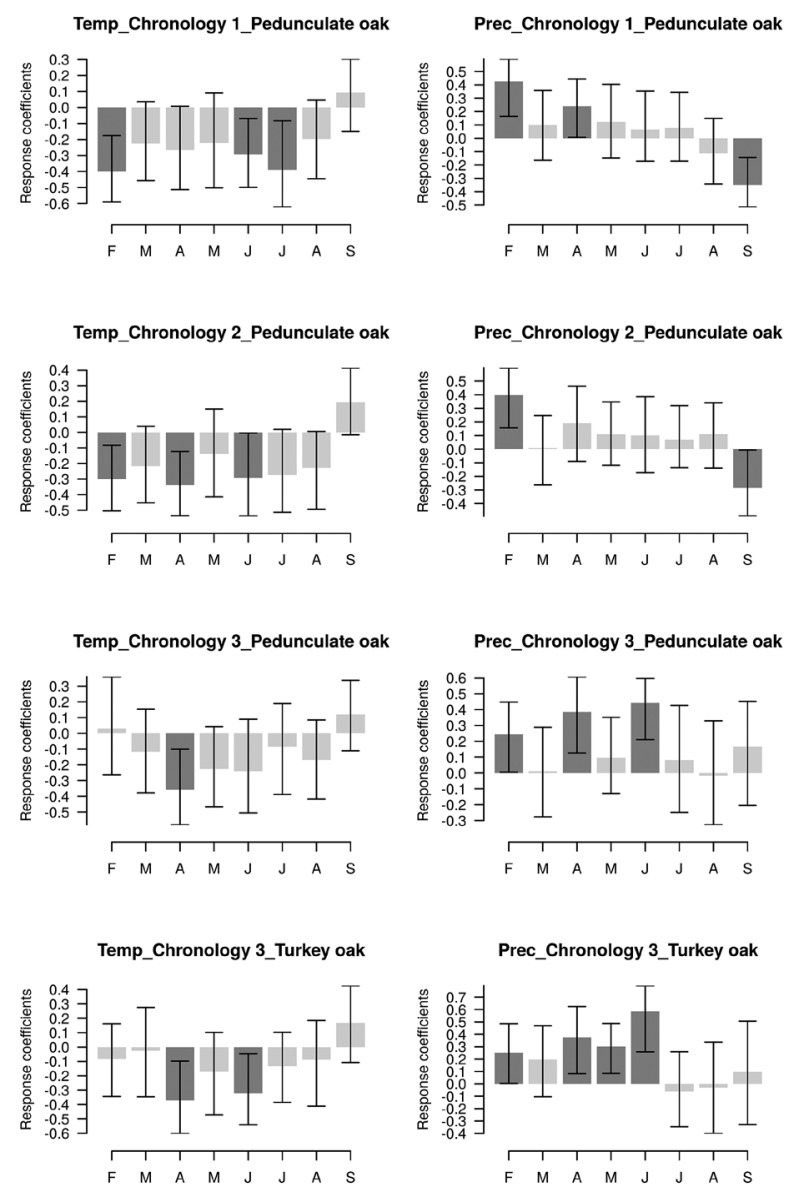

Temp_Chronology 5_European beech

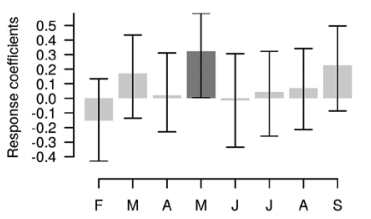

Prec_Chronology 5_European beech

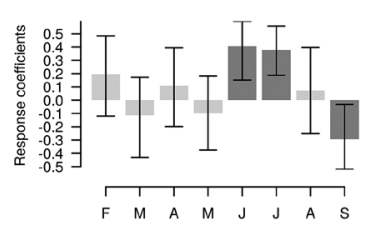

Temp_Chronology 6_Scots pine
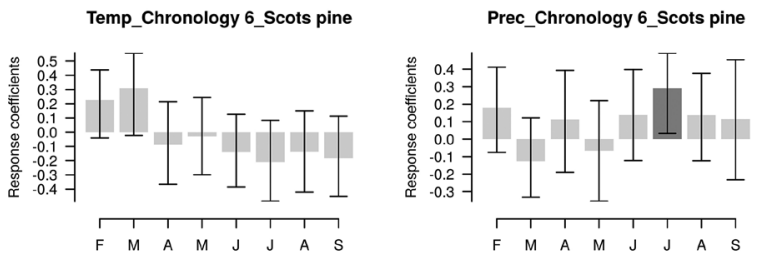

Fig. 3. Bootstrapped correlation coefficients between mean monthly temperature and monthly sum of precipitation for 3 locations and 4 studied tree species - light grey bars; dark grey bars represent statistically significant correlations, letters indicate months of the year of treering formation, the whiskers show the bootstrap confidence intervals 


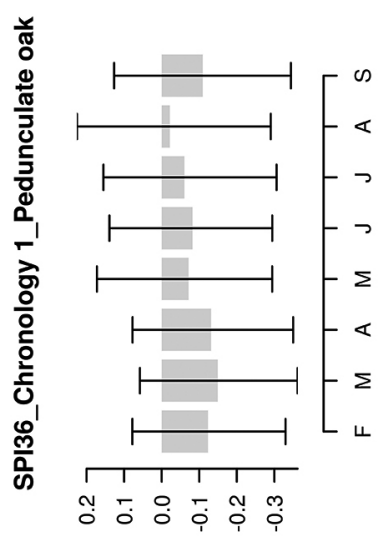

słuə!э!łəoว əsuodsəy
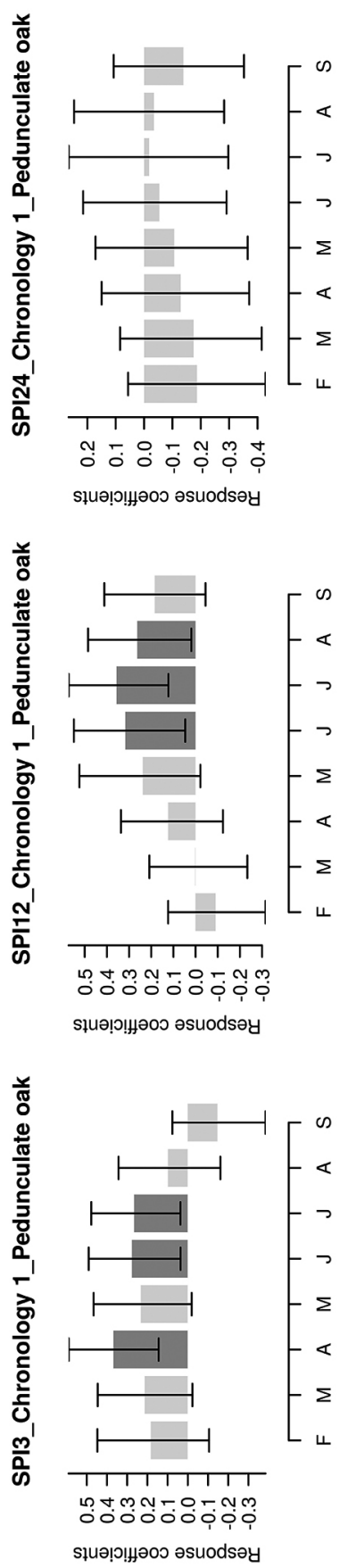
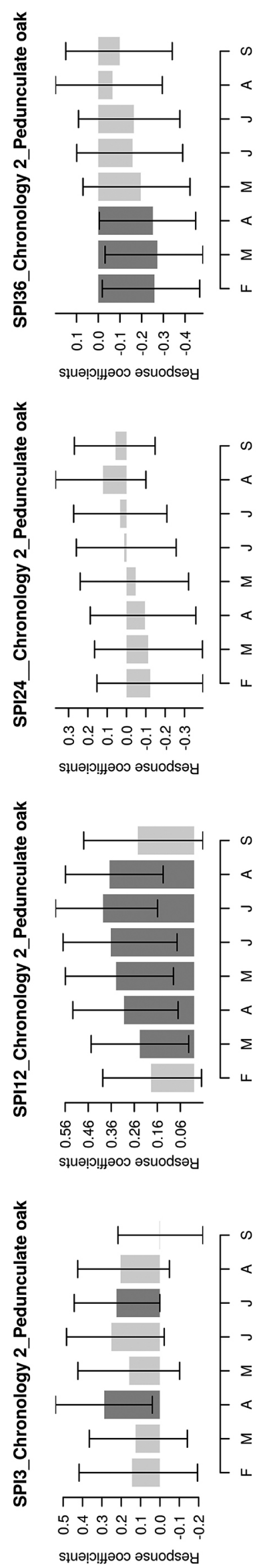

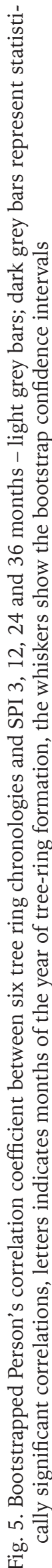

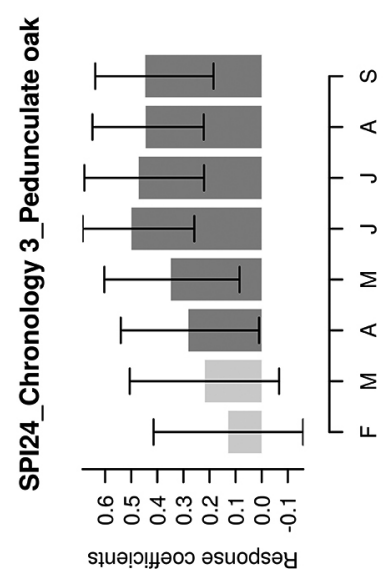
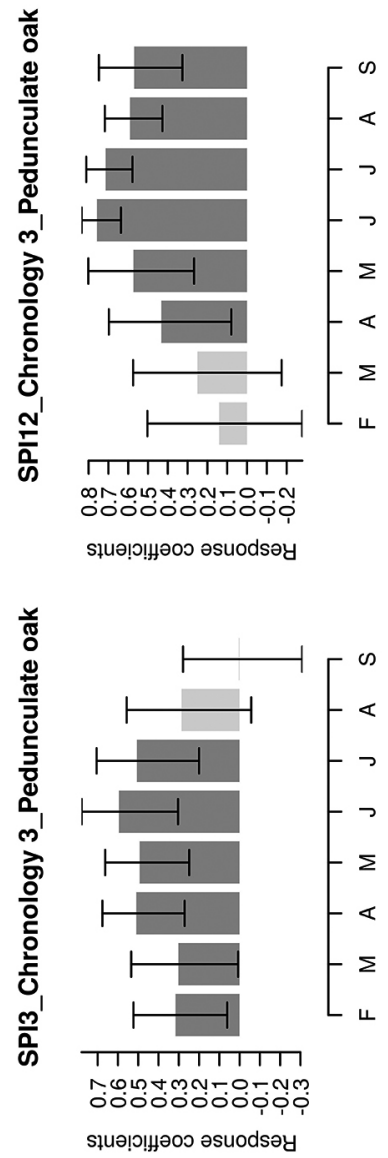

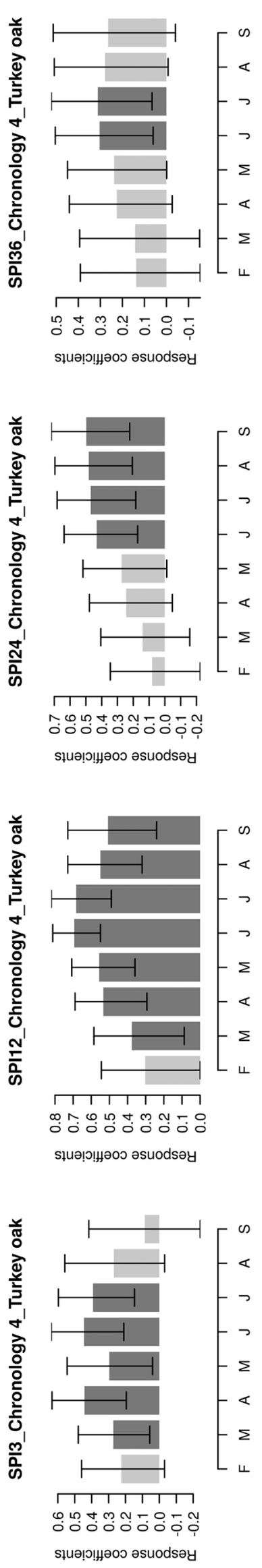
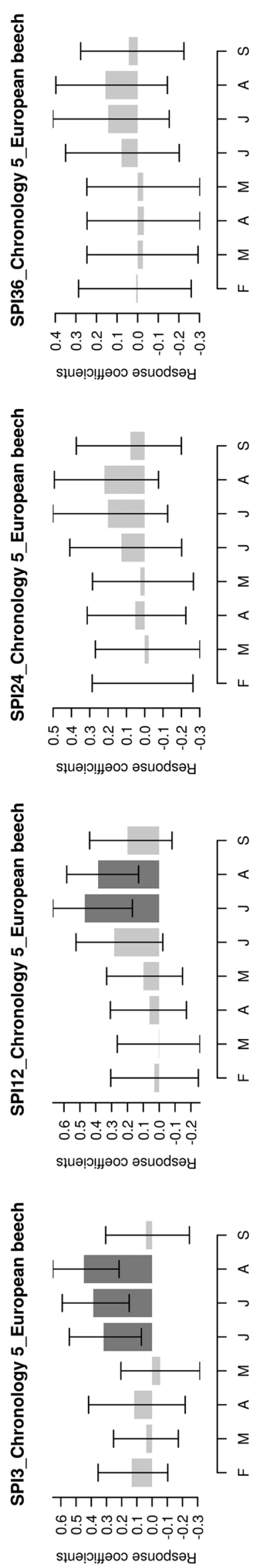

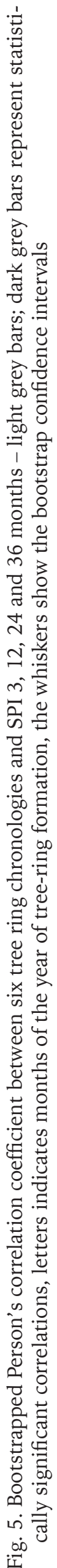

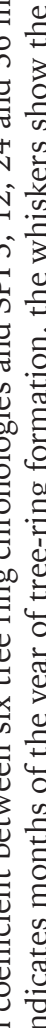
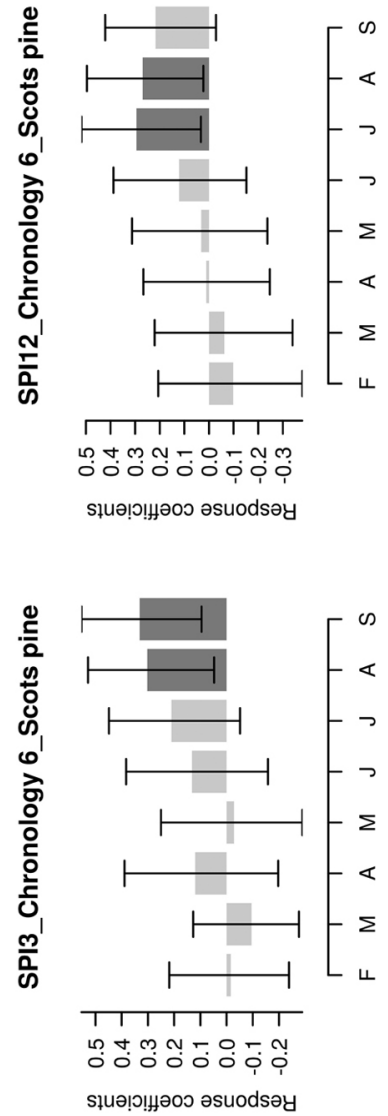
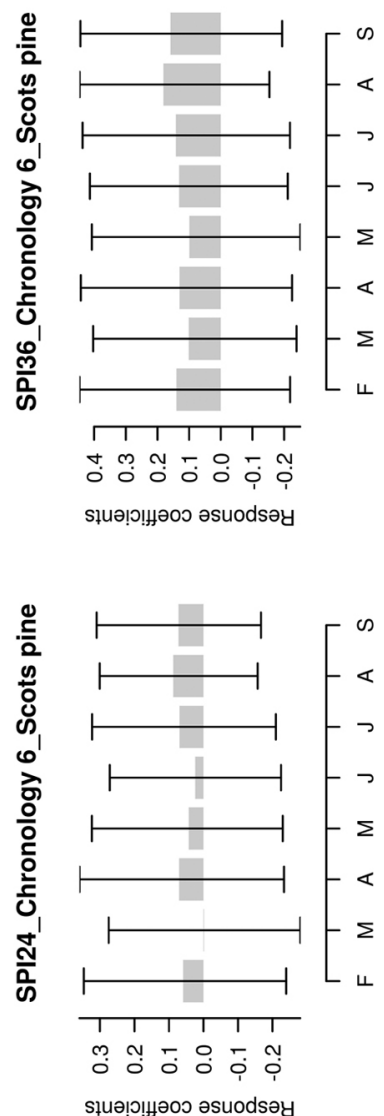

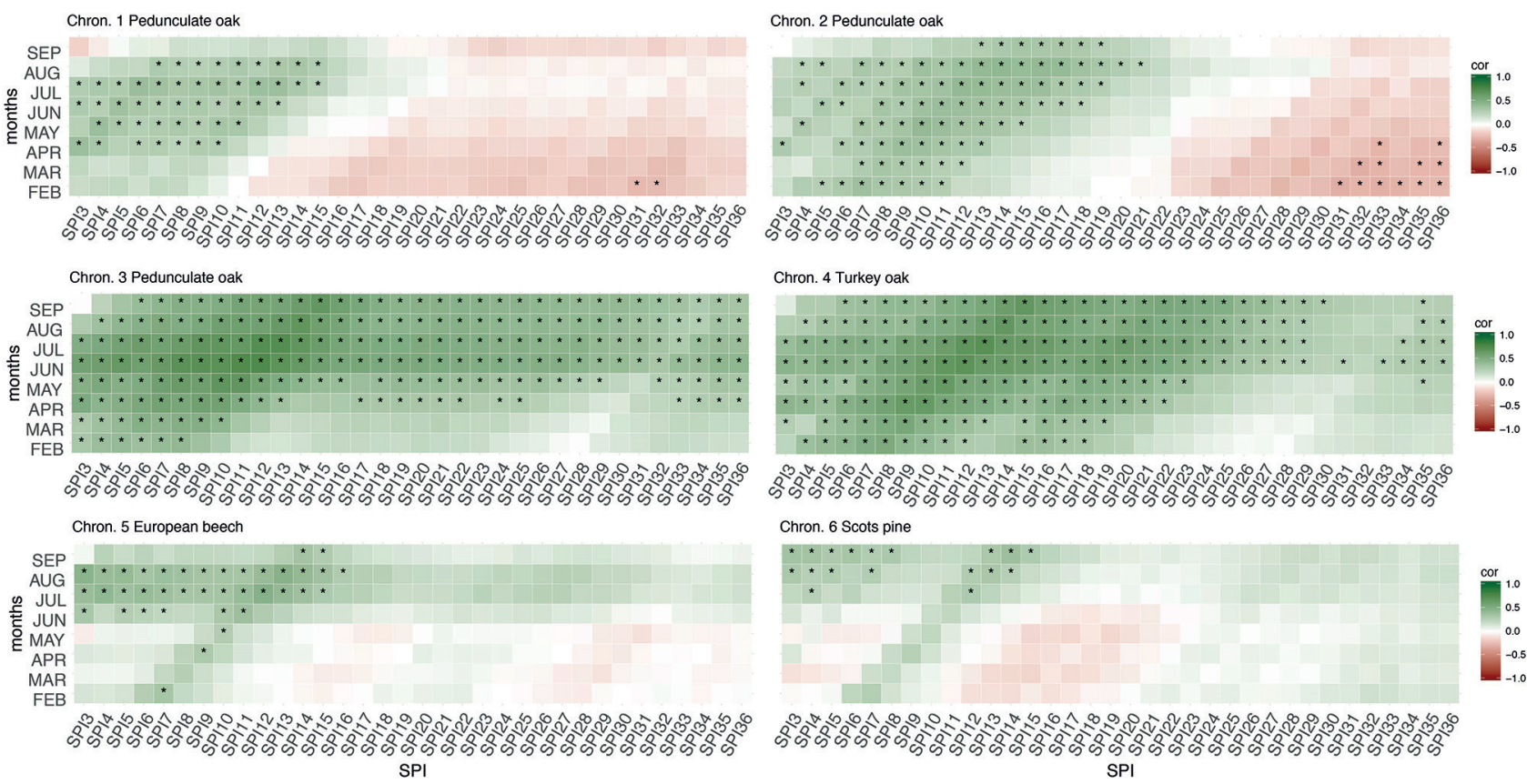

Fig. 6. Heatmaps of bootstrapped correlations between SPI-3 to SPI-36 for six tree-ring width chronologies; the legend shows correlation coefficients (green - positive correlations; red - negative); stars represent statistically significant correlations

which were hard to connect directly with tree growth or tree-ring formation.

Since temperature and precipitation could not provide a consistent climate growth relationship, we applied SPI to test the dependency between treering indices and climate. Exploratory analysis of 12-month SPI (Fig. 4) showed that SPI particularly well describes hydroclimatic conditions at the studied sites, with the late 1980s and early 1990s being more arid than average and the late 1990s and 2000s being much humid than average, with only short periods of more arid climatic conditions.

Based on this, we calculated bootstrapped correlations between TRWi chronologies for all four species and SPI $3-36$ from February to September of the year of tree ring formation (Fig. 5 and 6).

Generally, we found for all cases that growth was almost exclusively positively related to SPI indices (except for some cases of longer SPI periods, which were assumed to be related to climate patterns more than to growth). In the case of pedunculate oak from wetter sites (Chron.1 and 2), the long-term climate impact (drought as well as humid periods) was more pronounced with increasing number of months used in the calculation of SPI values, from SPI 3 up to approximately SPI 12 . In the cases of pedunculate and Turkey oak (Chron.3 and 4) on sites with deeper ground water level, the long-term impact of SPI values (up to SPI 36) were more pronounced. In the cases of beech and pine (Chron. 5 and 6) from the high elevation, humid site, statistically significant relations of SPI and growth were mostly concentrated in the summer months of approximately SPI 12 (Fig. 5 and 6).

\section{Long-term effect of drought}

After calculating all the correlation coefficients within six chronologies and SPI 3 to 36 from February to September of the year of tree-ring formation for the period 1961-2010 (all Pearson's correlation coefficients and their significances are plotted on Fig. 6), a clear pattern of the effect of the approx. 12-month weather conditions preceding the end of

Table 2. Highest correlations for six TRW chronologies from the pool of SPI 3 to 36 from February to September of the year of growth for the period 1961-2010

\begin{tabular}{llcc}
\hline & \multicolumn{1}{c}{ Species } & Highest positive correlation & Correlation coefficient \\
\hline Chron. 1 & Quercus robur L.- old-growth & JUL SPI-6 & 0.376 \\
Chron. 2 & Quercus robur L.- managed & AUG SPI-14 & 0.420 \\
Chron. 3 & Quercus robur L. managed, experienced mortality & JUN SPI-12 & 0.754 \\
Chron. 4 & Quercus cerris L. - managed, experienced mortality & JUL SPI-13 & 0.711 \\
Chron. 5 & Fagus sylvatica L. - managed & JUL SPI-12 & 0.469 \\
Chron. 6 & Pinus sylvestris L. - managed & SEP SPI-14 & 0.364 \\
\hline
\end{tabular}


the current summer (droughts as well as humid periods) becomes visible. The strongest positive correlations for five out of six cases were between SPI 12 and SPI 14 from June to September (Table 2), meaning that high growth rates can be expected when the autumn of the previous year and winter, spring and summer of the current year had above usual precipitation, and vice versa. In some cases, correlations with SPI from the second and third year before the formation of the current-year ring of $Q$. robur and $Q$. cerris still remained significant and high, as was the case with Chron. 3 and 4.

\section{Discussion}

\section{Correlation between growth and SPI}

Growth was driven by precipitation during the current year, as expected, but it was also distinctive that all four species at different sites showed the highest correlation between tree-ring widths and cumulative precipitation for approximately a year prior to the ring formation (Table 2).

Studies of oak growth and its response to climate have shown that oaks are sensitive to lack of water in the early summer months and, in particular, in the month preceding the onset of ring formation. The relationship between oak radial growth and climate at multiple sites in Britain was evaluated in the 1980s, with the finding that above average precipitation during the growing season and above average temperatures at the beginning of the summer positively affect growth (Pilcher \& Gray, 1982). Rybníček et al. (2016) studied oak response to climate in the central Czech Republic and found that trees respond positively to above average precipitation in the March-May period. This was similar to the finding of Nechita et al. (2017) from the Carpathian region, in which oaks responded positively to April-June precipitation. The response of oaks in the Pannonian lowlands was slightly different to the aforementioned findings. In Slovenia and Hungary, oaks had a narrower window of response; a significant response was found in above average precipitation in the June-July period (Čater \& Levanič, 2004; Čufar et al., 2008a; Kern et al., 2013; Levanič et al., 2011). The temperature signal in oak tree-rings has also been tested; it was found to be weak to non-existent. We found the oak response to be comparable to those from the Pannonian lowlands (e.g., Slovenia and Hungary). The amount of precipitation, the water level of the main rivers (Stojanović et al., 2015c) and drought (Levanič et al., 2011) are the main driving factors of growth (and decline) of oaks. It is particularly interesting that, despite the difference in age and management (Chron.1 300 years, virgin stand under strict protection and no management and Chron. 2. 140 year-old stand, regularly managed by the shelter-wood system; first stand flooded by Sava River, second protected from flooding), Chron. 1 and 2 stands expressed fairly similar patterns in response to long-term precipitation expressed as SPI (Fig. 6). In both cases, 12-month drought conditions ending with the current summer played an important role in supporting growth. In comparison to beech and pine, oaks showed a stronger correlation with long-term trends. Q. robur and Q. cerris trees (Chron. 3 and 4) experienced mortality during 2013 (Stojanović et al., 2015b). A number of studies have shown that sustained drought over an extended period (e.g. Berdanier \& Clark, 2016; Bhuyan et al., 2017; Levanič et al., 2011) and/or on a wider scale (e.g., south-eastern US forests) induces mortality (Allen et al., 2010; Berdanier \& Clark, 2016; McDowell et al., 2015; Park Williams et al., 2013). Our results agree with these findings in the way that they explain longterm relations between the cumulative influence of precipitation (expressed through SPI 3-36) and growth. We found that SPI can explain changes in growth rates. The highest positive correlation coefficients for Chron. 3 and 4 were above 0.7 for June SPI 12 and July SPI 13 (Table 2), while correlations were significant up to SPI 36 (Fig. 6). which implies an association between the growth of $Q$. robur and $Q$. cerris and long-term climatic conditions.

Growth of beech and Scots pine at the high elevation site Zlatibor was less limited by precipitation (or temperature). There was only a weak correlation between beech growth and any of the climatic parameters, which indicates almost optimal conditions for growth of beech and Scots pine. The short term effect of drought (SPI-3 and SPI-12) was the only significant factor positively influencing the growth of beech at the high elevation site. This is in accordance with the study by Bhuyan et al. (2017). Other studies from the wider region have highlighted the importance of above average precipitation for the growth of beech (Čufar et al., 2008b; Di Filippo et al., 2007; Garamszegi \& Kern, 2014) and they also connect the response with the occurrence of drought. Only Tegel et al. (2014) found the temperature signal to be more important than the drought signal, although they also found that the latter (scPDSI) is almost equally important as the temperature signal.

Scots pine, on the other hand, is a very plastic tree species. It can grow at different sites, in different climatic zones and at different elevations. In our study at the high elevation site Zlatibor, there was a similar response to climatic conditions as with beech. Temperature or precipitation played little or no role in the growth of Scots pine at high elevation; the only factor affecting growth was drought (SPI-3 and SPI-12), which is an indication of potential limitation posed 
by climate if climate changes tend towards decreasing precipitation. Our research is in accordance with the findings of the other authors who found that the growth of Scots pine in the studied region mainly depends on the amount of available precipitation (Misi \& Náfrádi, 2016) or severity of drought (Misi \& Náfrádi, 2017) and less on temperature (Sidor \& Popa, 2015). Some authors found an indirect connection between climate and growth of Scots pine - Poljanšek et al. (2015) found a close connection between a hot and dry summer and the number of needles of the terminal bud, while Panayotov et al. (2012) found a connection between drought and partial or complete absence of latewood if the summer in the year of ring formation was dry and warm.

\section{When does drought impact tree-growth - memory effect of a previous-year drought?}

In our case, the previous year's precipitation deficit (which has been frequent in recent decades and is assumed to be the leading cause of mass mortality of oak forest in the region of SE Europe (Cailleret et al., 2017; Stojanović et al., 2015b; Stojanović et al., 2015c), negatively impacted on the growth of all four species at all sites (SPI values that reach the previous year, Fig. 6), despite the amplitude difference between the low and high elevation sites, which were $400 \mathrm{~mm}$ of precipitation, $4^{\circ} \mathrm{C}$ in temperature and $1000 \mathrm{~m}$ in elevation (Table 1). It can be assumed that the current and previous year's precipitation deficit had the strongest impact on growth reduction (bearing in mind summer SPI 12 as the distinct predictor Fig. 5 \& 6). Our results from a geographically limited region of SE Europe support these findings. Research in old growth European beech forests in Italy provided results suggesting that previous-summer drought can be considered to be the main growth limiting factor (Piovesan et al., 2008). Research into P. sylvestris $20^{\text {th }}$ century mortality patterns indicated that multi-year drought periods lead to decline and an increase in the long-term risk of tree mortality (Bigler et al., 2006).

In a recent study by Bhuyan et al. (2017), the response of a variety of tree species in three climate zones (temperate, Mediterranean and continental) to climate was investigated, with an emphasis on various drought indices, including SPI on a $1,6,12$, 24, 36-month scale. This study, however, did not take into consideration chronologies from floodplains with a continental climate and southern sites of beech in a mountainous region. Comparison of their results with ours shows that they also found a response to long-term drought in pedunculate oak tree-rings in regions with a temperate climate (Fig.
6) and that the response of beech in a continental climate was different to that in our study - in Bhuyan's study, the beech response to long-term drought is clearly visible, while in our study, beech only shows a response up to 14-month SPI (Fig. 6). Our results are similar in Scots pine - in both studies, the response is unclear and limited to shorter-period SPI (Fig. 6).

We confirmed a significant long-term correlation between SPI 36 for June, July and August for pedunculate and Turkey oak at the dry site (Fig. 6). If the decrease in growth is considered more deeply, a reversible decrease in growth can happen, as long as a specific threshold in terms of hydraulic failure is not reached and gas emboli become trapped in the water transport system, which finally results in mortality (Choat et al., 2012). Carbon starvation may also be very important for the tree mortality phenomenon. It is closely related to the phenomenon of hydraulic failure and happens when carbon acquisition and storage mobilization are unable to support metabolic functions (McDowell, 2011). Physiological changes are gradually translated into organ dysfunction. Delayed consequences of drought can be seen through intra-annual variations in wood formation, irregular twig growth and fruit production (Bréda et al., 2006).

\section{SPI perspectives for application in forest management}

The straightforwardness of the SPI index, which arises from the fact that only monthly precipitation is needed for the calculation, is of critical importance for the future implementation of SPI in forestry practice. It is spatially consistent, probabilistic (it can be effectively used in risk and decision analyses), and it can be adjusted to specific time periods of interest (Guttman, 1998). The advantage of SPI in terms of simplicity, on the other hand, could also be a drawback if the evapotranspiration aspect is important (Trenberth et al., 2014). SPI measures water supply very well but it does not take into account evapotranspiration, which is used in another index called SPEI (Vicente-Serrano et al., 2010). In our case, we calculated SPEI for four oak chronologies, which in preliminary analysis did not provide better correlations with growth than SPI (some of those results are published in Stojanović et al. (2015a). In addition to its simplicity, SPI possesses robustness in comparison to, e.g., mean monthly precipitation, since different periods can be utilized (such as 3 to 36 months, as in our case) and adapted for use in different stands, species or regions. It can thus be concluded that, except in cases when its use is proved not to be justified or more complex alternatives such as SPEI are available, SPI can be effectively used for assessing climate growth relationships, due to its simplicity and 
universality. With the advance of new technologies, monitoring and assessment of drought conditions and their impact on forests may in future be strongly supported by remote sensing data and advanced machine learning techniques (Park et al., 2016). In regions in which climatic conditions of the previous year strongly affect growth in the current year, as in the case of the sites in SE Europe examined in this study, SPI may be well utilized in predictive modelling and, consequently, employed in forestry practice.

\section{Conclusions}

Species at lower, drier sites (oaks) were more sensitive to the long-term effects of precipitation (SPI of 12 months and more), in comparison to species at higher elevations, with lower temperatures and larger amounts of precipitation (beech and pine). SPI12 for summer months could be a good predictor of positive and negative growth for different species at different sites. The strongest positive correlations for five of six chronologies were between 12 and 14-month SPI from June to September. Meaning that, in general, growth rates depend on precipitation in autumn of the previous year and winter, spring and summer of the current year. The long-term effect of precipitation (up to SPI 36) significantly influenced growth of oaks at the dry site.

\section{Acknowledgment}

DS, BM and SO acknowledge financial support for the project by the Ministry of Education and Science of the Republic of Serbia - "Studying climate change and its influence on the environment: impacts, adaptation, mitigation" (III 43007). DS acknowledges the support of EU COST Action European Mixed Forests - Integrating Scientific Knowledge in Sustainable Forest Management - (EuMIXFOR) through a shortterm scientific mission in Ljubljana. TL acknowledges financial support from the Slovenian Research Agency (research core funding No. P4-0107 "Forest biology, ecology and technology" and project J4-8216 "Mortality of lowland oak forests - consequence of lowering underground water or climate change?".

\section{References}

Allen CD, Breshears DD \& McDowell NG (2015) On underestimation of global vulnerability to tree mortality and forest die-off from hotter drought in the Anthropocene. Ecosphere 6: 1-55. doi:10.1890/es15-00203.1.

Allen CD, Macalady AK, Chenchouni H, Bachelet D, McDowell N, Vennetier M, Kitzberger T, Rigling
A, Breshears DD, Hogg EH, Gonzalez P, Fensham R, Zhang Z, Castro J, Demidova N, Lim J-H, Allard G, Running SW, Semerci A \& Cobb N (2010) A global overview of drought and heat-induced tree mortality reveals emerging climate change risks for forests. Forest Ecology and Management 259: 660-684. doi:10.1016/j.foreco.2009.09.001.

Alley WM (1984) The Palmer Drought Severity Index: limitations and assumptions. Journal of Climate and Applied Meteorology 23: 1100-1109. doi:10.1175/1520-0450(1984)023<1100:tpdsil > 2.0.co; 2 .

Anderegg WRL, Hicke JA, Fisher RA, Allen CD, Aukema J, Bentz B, Hood S, Lichstein JW, Macalady AK, McDowell N, Pan Y, Raffa K, Sala A, Shaw JD, Stephenson NL, Tague C \& Zeppel M (2015) Tree mortality from drought, insects, and their interactions in a changing climate. New Phytologist 208: 674-683. doi:10.1111/nph.13477.

Asadi Zarch M, Malekinezhad H, Mobin MH, Dastorani MT \& Kousari MR (2011) Drought monitoring by Reconnaissance Drought Index (RDI) in Iran. Water Resources Management 25: 34853504. doi:10.1007/s11269-011-9867-1.

Baillie MGL \& Pilcher JR (1973) A simple crossdating program for tree-ring research. Tree-Ring Bulletin 33: 7-14.

Beguería S, Vicente-Serrano SM, Reig F \& Latorre B (2013) Standardized precipitation evapotranspiration index (SPEI) revisited: parameter fitting, evapotranspiration models, tools, datasets and drought monitoring. International Journal of Climatology 34: 3001-3023. doi:10.1002/joc.3887.

Berdanier AB \& Clark JS (2016) Multiyear drought-induced morbidity preceding tree death in southeastern U.S. forests. Ecological Applications 26: 17-23. doi:10.1890/15-0274.

Bhuyan U, Zang C \& Menzel A (2017) Different responses of multispecies tree ring growth to various drought indices across Europe. Dendrochronologia 44: 1-8. doi:10.1016/j.dendro.2017.02.002.

Bigler C, Bräker OU, Bugmann H, Dobbertin M \& Rigling A (2006) Drought as an inciting mortality factor in Scots pine stands of the Valais, Switzerland. Ecosystems 9: 330-343. doi:10.1007/ s10021-005-0126-2.

Bréda N, Huc R, Granier A \& Dreyer E (2006) Temperate forest trees and stands under severe drought: a review of ecophysiological responses, adaptation processes and long-term consequences. Annals of Forest Science 63: 625-644. doi:10.1051/forest:2006042.

Cailleret M, Jansen S, Robert EMR, Desoto L, Aakala T, Antos JA, Beikircher B, Bigler C, Bugmann H, Caccianiga M, Cada V, Camarero JJ, Cherubini P, Cochard H, Coyea MR, Cufar K, Das AJ, Davi H, Delzon S, Dorman M, Gea-Izquierdo G, Gillner S, 
Haavik LJ, Hartmann H, Heres AM, Hultine KR, Janda P, Kane JM, Kharuk VI, Kitzberger T, Klein $\mathrm{T}$, Kramer K, Lens F, Levanic T, Linares Calderon JC, Lloret F, Lobo-Do-Vale R, Lombardi F, Lopez Rodriguez R, Makinen H, Mayr S, Meszaros I, Metsaranta JM, Minunno F, Oberhuber W, Papadopoulos A, Peltoniemi M, Petritan AM, Rohner B, Sanguesa-Barreda G, Sarris D, Smith JM, Stan AB, Sterck F, Stojanovic DB, Suarez ML, Svoboda M, Tognetti R, Torres-Ruiz JM, Trotsiuk V, Villalba R, Vodde F, Westwood AR, Wyckoff PH, Zafirov N \& Martinez-Vilalta J (2017) A synthesis of radial growth patterns preceding tree mortality. Global Change Biology 23: 1675-1690. doi:10.1111/ gcb.13535.

Carnicer J, Coll M, Ninyerola M, Pons X, Sanchez G \& Penuelas J (2011) Widespread crown condition decline, food web disruption, and amplified tree mortality with increased climate changetype drought. Proceedings of the National Academy of Sciences 108: 1474-1478. doi:10.1073/ pnas.1010070108.

Čater M \& Levanič T (2004) Increment and environmental conditions in two Slovenian pedunculate-oak forest complexes. Ekologia-Bratislava 23: 353-365.

Charney ND, Babst F, Poulter B, Record S, Trouet VM, Frank D, Enquist BJ \& Evans MEK (2016) Observed forest sensitivity to climate implies large changes in 21st century North American forest growth. Ecology Letters 19: 1119-1128. doi:10.1111/ele.12650.

Choat B, Jansen S, Brodribb TJ, Cochard H, Delzon S, Bhaskar R, Bucci SJ, Feild TS, Gleason SM, Hacke UG, Jacobsen AL, Lens F, Maherali H, Martinez-Vilalta J, Mayr S, Mencuccini M, Mitchell PJ, Nardini A, Pittermann J, Pratt RB, Sperry JS, Westoby M, Wright IJ \& Zanne AE (2012) Global convergence in the vulnerability of forests to drought. Nature 491: 752-755. doi:10.1038/nature11688.

Cook ER (1985) Time series analysis approach to tree ring standardization. Laboratory of Tree-Ring Research, University of Arizona, Tucson.

Cook ER \& Holmes RL (1999) Program ARSTAN chronology development with statistical analysis (users manual for program ARSTAN). Laboratory of Tree-Ring Research, University of Arizona, Tucson.

Čufar K, De Luis M, Eckstein D \& Kajfež-Bogataj L (2008a) Reconstructing dry and wet summers in SE Slovenia from oak tree-ring series. International Journal of Biometeorology 52: 607-615. doi:10.1007/s00484-008-0153-8.

Čufar K, De Luis M, Horvat E \& Prislan P (2008b) Main patterns of variability in beech tree-ring chronologies from different sites in Slovenia and their relation to climate. Zbornik gozdarstva in lesarstva 87: 123-134.

Dale VH, Joyce LA, McNulty S, Neilson RP, Ayres MP, Flannigan MD, Hanson PJ, Irland LC, Lugo AE, Peterson CJ, Simberloff D, Swanson FJ, Stocks BJ \& Michael Wotton B (2001) Climate change and forest disturbances. BioScience 51: 723-734. doi:10.1641/0006-3568(2001)051[0723:ccafd]2.0.co;2.

Di Filippo A, Biondi F, Čufar K, De Luis M, Grabner M, Maugeri M, Presutti Saba E, Schirone B \& Piovesan G (2007) Bioclimatology of beech (Fagus sylvatica L.) in the Eastern Alps: spatial and altitudinal climatic signals identified through a treering network. Journal of Biogeography 34: 18731892. doi:10.1111/j.1365-2699.2007.01747.x.

Eckstein D \& Bauch J (1969) Beitrag zur rationalisierung eines dendrochronologischen verfahrens und zur analyse seiner aussagesicherheit. Forstwissenschaftliches Centralblatt 88: 230-250.

Feldpausch TR, Phillips OL, Brienen RJW, Gloor E, Lloyd J, Lopez-Gonzalez G, Monteagudo-Mendoza A, Malhi Y, Alarcón A, Álvarez Dávila E, Alvarez-Loayza P, Andrade A, Aragao LEOC, Arroyo L, Aymard C GA, Baker TR, Baraloto C, Barroso J, Bonal D, Castro W, Chama V, Chave J, Domingues TF, Fauset S, Groot N, Honorio Coronado E, Laurance S, Laurance WF, Lewis SL, Licona JC, Marimon BS, Marimon-Junior BH, Mendoza Bautista C, Neill DA, Oliveira EA, Oliveira dos Santos C, Pallqui Camacho NC, Pardo-Molina G, Prieto A, Quesada CA, Ramírez F, Ramírez-Angulo H, Réjou-Méchain M, Rudas A, Saiz G, Salomão RP, Silva-Espejo JE, Silveira M, ter Steege H, Stropp J, Terborgh J, Thomas-Caesar R, van der Heijden GMF, Vásquez Martinez R, Vilanova E \& Vos VA (2016) Amazon forest response to repeated droughts. Global Biogeochemical Cycles 30: 964982. doi:10.1002/2015GB005133.

Garamszegi B \& Kern Z (2014) Climate influence on radial growth of Fagus sylvatica growing near the edge of its distribution in Bükk Mts., Hungary. Dendrobiology 72: 93-102. doi:10.12657/denbio.072.008.

Guttman NB (1998) Comparing the Palmer Drought Index and the Standardized Precipitation Index. Journal of the American Water Resources Association 34: 113-121.

Guttman NB (1999) Accepting the Standardized Precipitation Index: a calculatation algorithm. JAWRA Journal of the American Water Resources Association 35: 311-322. doi:10.1111/j.1752-1688.1999. tb03592.x.

Jump AS, Hunt JM \& Peñuelas J (2006) Rapid climate change-related growth decline at the southern range edge of Fagus sylvatica. Global Change 
Biology 12: 2163-2174. doi:10.1111/j.13652486.2006.01250.x.

Kern Z, Patkó M, Kázmér M, Fekete J, Kele S \& Pályi Z (2013) Multiple tree-ring proxies (earlywood width, latewood width and 13C) from pedunculate oak (Quercus robur L.), Hungary. Quaternary International 293: 257-267. doi:10.1016/j. quaint.2012.05.037.

Levanič T (2007) ATRICS - A new system for image acquisition in dendrochronology. Tree-Ring Research 63: 117-122.

Levanič T, Čater M \& McDowell NG (2011) Associations between growth, wood anatomy, carbon isotope discrimination and mortality in a Quercus robur forest. Tree Physiology 31: 298-308. doi:10.1093/treephys/tpq111.

Lindner M, Maroschek M, Netherer S, Kremer A, Barbati A, Garcia-Gonzalo J, Seidl R, Delzon S, Corona P, Kolström M, Lexer MJ \& Marchetti M (2010) Climate change impacts, adaptive capacity, and vulnerability of European forest ecosystems. Forest Ecology and Management 259: 698-709. doi:10.1016/j.foreco.2009.09.023.

Littell JS, Peterson DL, Riley KL, Liu Y \& Luce CH (2016) A review of the relationships between drought and forest fire in the United States. Global Change Biology 22: 2353-2369. doi:10.1111/ gcb.13275.

Maracchi G, Sirotenko O \& Bindi M (2005) Impacts of present and future climate variability on agriculture and forestry in the temperate regions: Europe. Climatic Change 70: 117-135. doi:10.1007/ s10584-005-5939-7.

McDowell NG (2011) Mechanisms linking drought, hydraulics, carbon metabolism, and vegetation mortality. Plant Physiology 155: 1051-1059. doi:10.1104/pp.110.170704.

McDowell NG, Williams AP, Xu C, Pockman WT, Dickman LT, Sevanto S, Pangle R, Limousin J, Plaut J, Mackay DS, Ogee J, Domec JC, Allen CD, Fisher RA, Jiang X, Muss JD, Breshears DD, Rauscher SA \& Koven C (2015) Multi-scale predictions of massive conifer mortality due to chronic temperature rise. Nature Climate Change 6: 295-300. doi:10.1038/nclimate2873.

McKee TB, Doesken NJ \& Kliest J (1993) The relationship of drought frequency and duration to time scales: Proceedings of the 8th Conference on Applied Climatology. American Meteorological Society, Boston, MA, USA, Anaheim, CA, USA, pp. 179-184.

Misi D \& Náfrádi K (2016) Possibility of identification of negative extreme climatic events using Pinus sylvestris tree-rings in Transdanubia, Hungary. Dendrobiology 75: 45-54. doi:10.12657/denbio.075.005.
Misi D \& Náfrádi K (2017) Growth response of Scots pine to changing climatic conditions over the last 100 years: a case study from Western Hungary. Trees 31: 919-928. doi:10.1007/s00468-016$1517-z$.

Mueller RC, Scudder CM, Porter ME, Talbot Trotter R, Gehring CA \& Whitham TG (2005) Differential tree mortality in response to severe drought: evidence for long-term vegetation shifts. Journal of Ecology 93: 1085-1093. doi:10.1111/j.13652745.2005.01042.x.

Nechita C, Popa I \& Eggertsson O (2017) Climate response of oak (Quercus spp.), an evidence of a bioclimatic boundary induced by the Carpathians. Science of the Total Environment 599-600: 15981607. doi:10.1016/j.scitotenv.2017.05.118.

Panayotov MP, Zafirov N \& Cherubini P (2012) Fingerprints of extreme climate events in Pinus sylvestris tree rings from Bulgaria. Trees 27: 211-227. doi:10.1007/s00468-012-0789-1.

Park S, Im J, Jang E \& Rhee J (2016) Drought assessment and monitoring through blending of multi-sensor indices using machine learning approaches for different climate regions. Agricultural and Forest Meteorology 216: 157-169. doi:10.1016/j.agrformet.2015.10.011.

Park Williams A, Allen CD, Macalady AK, Griffin D, Woodhouse CA, Meko DM, Swetnam TW, Rauscher SA, Seager R, Grissino-Mayer HD, Dean JS, Cook ER, Gangodagamage C, Cai M \& McDowell NG (2013) Temperature as a potent driver of regional forest drought stress and tree mortality. Nature Climate Change 3: 292-297. doi:10.1038/ nclimate1693.

Pilcher JR \& Gray B (1982) The relationships between oak tree growth and climate in Britain. The Journal of Ecology 70: 297-304. doi:10.2307/2259880.

Piovesan G, Biondi F, Filippo AD, Alessandrini A \& Maugeri M (2008) Drought-driven growth reduction in old beech (Fagus sylvatica L.) forests of the central Apennines, Italy. Global Change Biology 14: 1265-1281. doi:10.1111/j.13652486.2008.01570.x.

Poljanšek S, Levanič T, Ballian D \& Jalkanen R (2015) Tree growth and needle dynamics of $P$. nigra and $P$. sylvestris and their response to climate and fire disturbances. Trees 29: 683-694. doi:10.1007/ s00468-014-1146-3.

Pretzsch H, del Río M, Ammer C, Avdagic A, Barbeito I, Bielak K, Brazaitis G, Coll L, Dirnberger G, Drössler L, Fabrika M, Forrester DI, Godvod K, Heym M, Hurt V, Kurylyak V, Löf M, Lombardi F, Matović B, Mohren F, Motta R, den Ouden J, Pach M, Ponette Q, Schütze G, Schweig J, Skrzyszewski J, Sramek V, Sterba H, Stojanović D, Svoboda M, Vanhellemont M, Verheyen K, Wellhausen K, Zlatanov T \& Bravo-Oviedo A (2015) Growth and 
yield of mixed versus pure stands of Scots pine (Pinus sylvestris L.) and European beech (Fagus sylvatica L.) analysed along a productivity gradient through Europe. European Journal of Forest Research 134: 927-947. doi:10.1007/s10342-0150900-4.

Rybníček M, Čermák P, Prokop O, Žid T, Trnka M \& Koláŕ T (2016) Oak (Quercus spp.) response to climate differs more among sites than among species in central Czech Republic. Dendrobiology 75: 55-65. doi:10.12657/denbio.075.006.

Sidor CG \& Popa I (2015) The influence of monthly and periodical meteorological parameters on the radial growth of Silver fir, Scots pine and larch in Banat. Bucovina Forestiera 15: 55-63.

Stojanović D, Levanič T \& Matović B (2015a) Correlation between different climate variables and indices and growth of Turkey oak (Quercus cerris L.). Topola 195-196: 23-29.

Stojanović D, Levanič T, Matović B \& Bravo-Oviedo A (2015b) Climate change impact on a mixed lowland oak stand in Serbia. Annals of Silvicultural Research 39: 94-99. doi:10.12899/asr-1126.

Stojanović D, Levanič T, Matović B \& Orlović S (2015c) Growth decrease and mortality of oak floodplain forests as a response to change of water regime and climate. European Journal of Forest Research 134: 555-567. doi:10.1007/s10342015-0871-5.

Stokes MA \& Smiley TL (1968) An introduction to tree-ring dating. 2nd edn. The University of Arizona Press, Tucson.

Szalai S, Auer I, Hiebl J, Milkovich J, Radim T, Stepanek P, Zahradnicek P, Bihari Z, Lakatos M, Szentimrey T, Limanowka D, Kilar P, Cheval S, Deak G, Mihic D, Antolovic I, Mihajlovic V, Nejedlik P, Stastny P, Mikulova K, Nabyvanets I, Skyryk O, Krakovskaya S, Vogt J, Antofie T \& Spinoni $\mathrm{J}$ (2013) Climate of the greater carpathian region - final technical report.
Tegel W, Seim A, Hakelberg D, Hoffmann S, Panev M, Westphal T \& Büntgen U (2014) A recent growth increase of European beech (Fagus sylvatica L.) at its Mediterranean distribution limit contradicts drought stress. European Journal of Forest Research 133: 61-71. doi:10.1007/s10342-0130737-7.

Trenberth KE, Dai A, van der Schrier G, Jones PD, Barichivich J, Briffa KR \& Sheffield J (2014) Global warming and changes in drought. Nature Climate Change 4: 17-22. doi:10.1038/nclimate2067.

Trumbore S, Brando P \& Hartmann H (2015) Forest health and global change. Science 349: 814-818. doi:10.1126/science.aac6759.

Tsakiris G, Pangalou D \& Vangelis H (2007) Regional drought assessment based on the Reconnaissance Drought Index (RDI). Water Resources Management 21: 821-833. doi:10.1007/s11269-0069105-4.

van Mantgem PJ \& Stephenson NL (2007) Apparent climatically induced increase of tree mortality rates in a temperate forest. Ecology Letters 10: 909916. doi:10.1111/j.1461-0248.2007.01080.x.

Vicente-Serrano SM, Beguería S \& López-Moreno JI (2010) A multiscalar drought index sensitive to global warming: The Standardized Precipitation Evapotranspiration Index. Journal of Climate 23: 1696-1718. doi:10.1175/2009jcli2909.1.

Zang C \& Biondi F (2013) Dendroclimatic calibration in R: The bootRes package for response and correlation function analysis. Dendrochronologia 31: 68-74. doi:http://dx.doi.org/10.1016/j.dendro.2012.08.001.

Zimmermann J, Hauck M, Dulamsuren C \& Leuschner C (2015) Climate warming-related growth decline affects Fagus sylvatica, but not other broadleaved tree species in Central European mixed forests. Ecosystems 18: 560-572. doi:10.1007/ s10021-015-9849-x. 